\title{
Implementasi Tujuan Jangka Menengah Dan Jangka Panjang Proyek Perubahan Oleh Camat Alumni Diklat Kepemimpinan Tingkat III di Kota Jambi
}

\author{
Bailah \\ Badan Pengembangan Sumber Daya Manusia Provinsi Jambi \\ e-mail: bailahsaleh_tuah@yahoo.co.id
}

\begin{abstract}
ABSTRAK
Penelitian ini dilatarbelakangi keinginan untuk mengetahui sejauh mana implementasi tujuan jangka menengah dan tujan jangka panjang proyek perubahan oleh alumni Diklat Kepemimpinan Tingkat III Pola Baru yang sudah diterapkan sejak pertengahan 2014 oleh Lembaga Administrasi Negara RI. Tujuan penelitian ini ialah untuk mendeskripsikan faktor-faktor yang mempengaruhi implementasi proyek perubahan oleh para pejabat yang bertanggungjawab terhadap pengelolaan program di instansinya. Teori yang digunakan dalam penelitian ini adalah teori implementasi Merilee S. Grindle yang menyatakan bahwa implementasi dipengaruhi oleh dua variabel besar, yakni isi kebijakan dan lingkungan kebijakan. Metode yang digunakan dalam penelitian ini ialah kualitatif deskriptif dengan data primer dan sekunder yang diperoleh melalui wawancara mendalam, observasi dan studi dokumentasi. Informan ditentukan dengan purposive sampling, yakni para Camat Alumni Diklat Kepemimpinan Tingkat III sebagai pengelola program, para pelaksana dan pemanfaat program. Triangulasi data dilakukan dengan metode triangulasi sumber. Hasil penelitian ini menunjukan bahwa implementasi tujuan jangka menengah proyek perubahan sudah berjalan baik dan sesuai dengan yang ditargetkan dan implementasi tujuan jangka panjang proyek perubahan juga berjalan baik dan sesuai dengan tujuannya. Walaupun demikan, perlu dilakukan penyempurnaan dalam beberapa aspek teknis impelementasi, seperti keterkaitan pihak ketiga dengan implementasi dan kemampuan mengikuti perkembangan teknologi informasi
\end{abstract}

Kata Kunci: Implemantasi, Diklatpim Tingkat III, Proyek Perubahan, Tujuan Jangka Menengah dan Jangka Panjang.

\section{PENDAHULUAN}

Untuk memperbaiki kualitas sektor publik sudah barang tentu diperlukan adanya kepemimpinan birokrasi yang visioner, berkarakter, dan mampu memimpin transformasi sektor publik. Dalam budaya paternalistik posisi pemimpin memiliki peran yang sangat strategis. Penguatan kapasitas kepemimpinan akan memiliki efek yang sangat besar terhadap kualitas penyelenggaraan pemerintahan. Upaya untuk membentuk kepemimpinan yang mumpuni dibirokrasi pemerintahan sampai saat ini memang masih belum optimal. Salah satu upaya yang dinilai dapat membentuk kepemimpinan birokrasi adalah melalui kegiatan pendidikan dan pelatihan.

Pada prinsipnya Kepemimpinan dapat dibentuk dan disiapkan, seperti halnya keberanian mengambil risiko, kemampuan berkomunikasi, dan memobilisasi sumberdaya dapat dilatih melalui pembelajaran yang berbasis pengalaman. Diklat Kepemimpinan ini bertujuan untuk melatih dan membangun skill aparatur meningkatkan kapasitas merencanakan, melaksanakan, mengelola konflik yang terjadi sebagai akibat perubahan, dan memastikan perubahan berjalan sesuai dengan ekspektasinya; menjual gagasan perubahan kepada pimpinan dan stakeholder yang ada di instansinya; mengimplementasikan proyek perubahan dalam leadership laboratory, mengelola proses perubahan yang sesungguhnya dibawah bimbingan mentor, coach, dan counselor; dan, melibatkan pimpinan masing-masing instansi dalam proses pembelajaran, apresiasi dan kepemilikan, peran pemimpin instansi untuk menyiapkan calon pemimpin sebagai proses kaderisasi.

Diklat kepemimpinan merupakan pendidikan dan pelatihan yang dirancang bagi pejabat pemerintah untuk membentuk dan mengembangkan mereka menjadi pemimpin perubahan. Kompetensi sebagai pemimpin perubahan akan terbentuk melalui praktik langsung di lapangan. 
Bentuk praktik langsung dalam diklatpim ini adalah dengan melaksanakan proyek perubahan di kantornya masing-maisng. Pelaksanaan proyek perubahan dimulai dengan menyusun rancangan proyek perubahan dilanjutkan implementasi proyek perubahan, dan menyusun laporan proyek perubahan.

\section{LANDASAN TEORI \\ 2.1.Konsep Kebijakan Publik}

Kebijakan publik merupakan suatu ilmu multidisipliner karena melibatkan banyak disiplin ilmu seperti ilmu politik, sosial, ekonomi dan psikologi. George C. Edwards III dan Ira Sharkansky dalam Suwitri (2008:10) mendefinisikan kebijakan publik sebagai suatu tindakan pemerintah yang berupa program-program pemerintah untuk pencapaian sasaran atau tujuan. Dari definisi diatas kita bisa melihat bahwa kebijakan publik memiliki kata kunci "tujuan", "nilai-nilai" dan "praktik".

\subsection{Teori Implementasi Merilee S Grindel}

Pendekatan Merilee S. Grindle dikenal dengan Implementation as A political and Administrative Procces yang secara bebas dapat diartikan implementasi adalah proses hasil kombinasi politik dan administrasi. Keberhasilan implementasi menurut Merilee S. Grindle (Wibawa, 2005:36) yang menjelaskan bahwa implementasi dipengaruhi oleh dua variabel besar, yakni isi kebijakan dan lingkungan (konteks) implementasi, kedua hal tersebut harus didukung oleh program aksi dan proyek individu yang didesain dan dibiayai berdasarkan tujuan kebijakan, sehingga dalam pelaksanaan kegiatan akan memberikan hasil berupa dampak pada masyarakat, individu dan kelompok serta perubahan dan penerimaan oleh masyarakat terhadap kebijakan yang terlaksana.

Variabel isi kebijakan menurut Grindle mencakup beberapa indikator yaitu:

1) Kepentingan kelompok sasaran atau target groups termuat dalam isi kebijakan.

2) Jenis manfaat yang diterima oleh target group.

3) Derajat perubahan yang diharapkan dari sebuah kebijakan.

4) Letak pengambilan keputusan.

5) Pelaksana program telah disebutkan dengan rinci, dan

6) Dukung oleh sumber daya yang dilibatkan.

Sedangkan variabel lingkungan kebijakan mencakup 3 indikator yaitu:

a) Seberapa besar kekuasaan, kepentingan, dan strategi yang dimiliki oleh para aktor yang terlibat dalam implementasi kebijakan.

b) Karakteristik lembaga dan rejim yang sedang berkuasa.

c) Tingkat kepatuhan dan responsivitas kelompok sasaran.

Di sini kebijakan yang menyangkut banyak kepentingan yang berbeda akan lebih sulit diimplementasikan dibanding yang menyangkut sedikit kepentingan. Oleh karenanya tinggirendahnya intensitas keterlibatan berbagai pihak (politisi, pengusaha, masyarakat, kelompok sasaran dan sebagainya) dalam implementasi kebijakan akan berpengaruh terhadap efektivitas implementasi kebijakan.

Dalam penelitian ini, kedua variabel pendekatan model Grindle ini dipakai sebagai pedoman untuk mengukur keberhasilan implementasi program yang ada. Hal ini dikarenakan kedua variabel dengan 9 (sembilan) indikator dalam model ini, peneliti anggap cocok dengan penelitian implementasi program karena sudah mempertimbangkan aspek lingkungan internal dan lingkungan eksternal sebagai faktor yang mempengaruhi implementasi. 


\section{METODE PENELITIAN}

Jenis penelitian ialah penelitian kualitatif, yaitu penelitian yang menghasilkan data deskriptif berupa kata-kata tertulis atau lisan dari orang-orang dan perilaku yang diamati (Bogdan dan Taylor J dalam Sofar Silaen, 2018:18). Data yang digunakan adalah data primer dan data sekunder. Informan dalam penelitian ini ditentukan dengan purposive sampling, yakni Para Camat Alumni Diklat Kepemimpinan Tingkat III di Kota Jambi sebagai pengelola, para pelaksana program dan pemanfaat program. Data Penelitian diperoleh melalui wawancara mendalam terhadap pengelola program, pelaksana program dan pemanfaat program. Dan juga dilakukan observasi dan studi dokumentasi dalam rangka mendukung kevalidan data (kroscek data). Keabsahan data yang didapat diuji dengan melakukan triangulasi sumber data dan dianalisis melalui tiga tahapan yaitu reduksi, penyajian dan penarikan kesimpulan

\section{HASIL DAN PEMBAHASAN}

Penelitian ini mendeskripsikan implementasi tujuan jangka menengah dan jangka panjang proyek perubahan 7 (tujuh) camat alumni Diklat Kepemimpinan Tingkat III berbasiskan teori Grindle yang meliputi 9 (sembilan) indikator yang mempengaruhi implementasi. Selanjutnya hasil dari penelitian 9 (sembilan) indikator ini penulis interpretasikan untuk menjawab pertanyaan penelitian seperti yang tertera diproposal penelitian. Hasil penelitian menunjukkan hal-hal sebagai berikut:

\subsection{Aspek kepentingan kelompok sasaran (target group) yang termuat dalam isi kebijakan.}

Dari hasil penelitian pada 7 proyek perubahan menunjukkan bahwa kepentingan kelompok sasaran termuat/tercakup dalam isi proyek perubahan. Dari 7 proyek perubahan setelah dianalisa menunjukkan bahwa tema/fokus proyek perubahan terbagi dalam 3 (tiga) kategori utama, yaitu : pelayanan, pemberdayaan, dan kinerja aparatur. Lima (5) proyek perubahan (Camat Paal Merah, Jelutung, Jambi Timur, Danau Sipin dan Pelayangan) berkorelasi langsung dengan kepentingan kelompok masyarakat dan sasaran masyarakat sebagai pemanfaat, dan 2 (dua) proyek perubahan (Camat Kota Baru dan Alam Barajo) berorientasi pada peningkatan kinerja aparatur daerah. Dua proyek perubahan yang berorientasi pada kinerja aparatur, jika ditelaah lebih lanjut menggambarkan hal yang berbeda secara signifikan. Satu proyek perubahan (Camat Kota Baru) dimaksudkan untuk meningkarkan kinerja aparatur yang berorientasi kepada peningkatan kinerja mereka dalam memberikan pelayanan kepada masyarakat. Jadi, simpulan sementara proyek perubahan Camat Kota Baru atas nama Ferialdi, S.Sos, pemanfaatnya secara langsung adalah aparatur, dan pemanfaat secara tidak langsung adalah masyarakat. Sementara, satu proyek perubahan lagi atas nama Camat Alam Barajo ditujukan untuk meningkatkan kinerja aparatur dalam memungut pajak/retribusi daerah/(PBB), artinya proyek perubahan ini berorientasi kepada peningkatan kapasitas ekonomi pemerintah daerah. Peningkatan kapasitas ekonomi pemerintah daerah ini secara riil akan membebani masyarakat karena di"wajibkan" membayar pajak/retribusi daerah (PBB). Gambaran lebih lengkapnya dapat dilihat pada tabel 1.

\subsection{Aspek jenis manfaat yang diterima oleh kelompok sasaran.}

Dari hasil penelitian 7 proyek perubahan. Empat (4) proyek perubahan yang bertemakan "pelayanan" dan 1 (satu) proyek perubahan yang bertemakan "pemberdayaan" jika dianalisis lebih dalam memberikan gambaran bahwa masyarakat akan memperoleh secara langsung manfaatnya dengan peningkatan pelayanan dan pemberdayaan kelompok masyarakat. Proyek perubahan Camat Jambi Timur, Camat Jelutung, Camat Danau Sipin, dan Camat Pelayangan 
berkorelasi dengan memberikan manfaat langsung kepada masyarakat dengan memberikan peningkatan kualitas pelayanan. Peningkatan pelayanan kepada masyarakat dilakukan dengan berbagai strategi, tergantung kompleksitas dan sumber daya yang dimiliki pada kecamatan masing-masing.

Analisis lebih lanjut menunjukkan bahwa strategi umum yang dipakai oleh para camat di Kota Jambi dalam meningkatkan pelayanan adalah dengan menggunakan teknologi informasi, melalui pelayanan berbasis elektornik yang dikenal dengan "e-Pelayanan". Analisis lebih lanjut menunjukkan bahwa Camat Jambi Timur, Camat Jelutung, Camat Danau Sipin dan Camat Pelayangan melakukan penerapan e-pelayanan melalui beberapa tahapan sebagai berikut: jangka pendek membangun koneksi jaringan dan persiapannya berupa penerbitan juknis/SOP dan sosialisasi, jangka menengah implementasi e-pelayanan dan sekaligus launchingnya dan jangka panjang stabilisasi pelayanan berbasis e-pelayanan.

Hasil dari wawancara dan observasi target group dilapangan (tabel 2) menunjukkan bahwa memang terjadi peningkatan kinerja pelayanan para camat secara umum dalam 1-2 tahun belakangan, walaupun dengan berbagai alasan dan catatan yang diberikan sebagai bahan perbaikan. Empat (4) proyek perubahan yang bertemakan "pelayanan" secara otomatis memberikan manfaat secara langsung kepada masyarakat penerima manfaat berupa peningkatan kinerja pelayanan yang diberikan oleh aparatur Pemerintah Kota Jambi.

Tabel 1. Kelompok Sasaran Proyek Perubahan

\begin{tabular}{|c|c|c|c|c|}
\hline No & Nama Peserta/NIP & Judul Proyek Perubahan & $\begin{array}{l}\text { Fokus/Tema } \\
\text { Proyek } \\
\text { Perubahan }\end{array}$ & $\begin{array}{c}\text { Kelompok } \\
\text { Sasaran }\end{array}$ \\
\hline 1. & $\begin{array}{l}\text { Feriadi, S.Sos/ } \\
\text { NIP.1970020919900310 } \\
02\end{array}$ & $\begin{array}{l}\text { Peningkatan Kinerja Kasi dan Staf } \\
\text { Kantor Camat Melalui Laporan } \\
\text { Kinerja di Kecamatan Kota Baru, } \\
\text { Kota Jambi }\end{array}$ & $\begin{array}{l}\text { Kinerja } \\
\text { Aparatur }\end{array}$ & Aparatur \\
\hline 2. & $\begin{array}{l}\text { Rahmat Sugiharto, } \\
\text { S.STP/ } \\
\text { NIP. } \\
\\
\begin{array}{ll}198004231999 \\
121001\end{array}\end{array}$ & $\begin{array}{l}\text { Pembangunan } \\
\text { Pelayanan Kelayanan dan } E- \\
\text { Terintegrasi Delurahan Yang } \\
\text { Sistem Informasi Datikasi } \\
\text { Kecamatan (SIDAK) di } \\
\text { Kecamatan Jambi Timur }\end{array}$ & Pelayanan & $\underset{\mathrm{t}}{\text { Masyaraka }}$ \\
\hline 3. & $\begin{array}{l}\text { Hj. Mursida, S.Pd/ } \\
\text { NIP. } \\
\qquad \begin{array}{l}196510201990 \\
022001\end{array}\end{array}$ & $\begin{array}{l}\text { Optimalisasi Pemberdayaan } \\
\text { Masyarakat Melalui Pemanfaatan } \\
\text { Lahan Terlantar di Kecamatan } \\
\text { Paal Merah Kota Jambi }\end{array}$ & Pemberdayaan & $\begin{array}{l}\text { Kelompok } \\
\text { Masyaraka } \\
\mathrm{t}\end{array}$ \\
\hline 4. & $\begin{array}{l}\text { Drs. Raden Jufri, ME/ } \\
\text { NIP. } \\
\qquad \begin{array}{l}196711251989 \\
081001\end{array}\end{array}$ & $\begin{array}{l}\text { Peningkatan Pelayanan Perizinan } \\
\text { dan Non-Perizinan Melalui } \\
\text { Pelayanan Administrasi Terpadu } \\
\text { Kecamatan (PATEN) di } \\
\text { Kecamatan Danau Sipin } \\
\text { Peningkatan Realisasi Penerimaan }\end{array}$ & Pelayanan & $\begin{array}{c}\text { Masyaraka } \\
\mathrm{t}\end{array}$ \\
\hline 5. & $\begin{array}{l}\text { Drs. Amran, ME/ } \\
\text { NIP.1969100519890810 } \\
02\end{array}$ & $\begin{array}{l}\text { Pajak Bumi dan Bangunan (PBB) } \\
\text { Melalui Pemutakhiran Data PBB } \\
\text { Oleh Kolektor di Kelurahan } \\
\text { Rawasari Kecamatan Alam Barajo }\end{array}$ & $\begin{array}{c}\text { Data Wajib } \\
\text { PBB }\end{array}$ & $\begin{array}{l}\text { Masyaraka } \\
\text { t Pembayar } \\
\text { PBB }\end{array}$ \\
\hline 6. & $\begin{array}{l}\text { Novianto, SE., ME/ } \\
\text { NIP. } \\
197211301992 \\
031003\end{array}$ & $\begin{array}{l}\text { Peningkatan Pelayanan } \\
\text { Administrasi Kecamatan Melalui } \\
\text { Aplikasi Pelayanan di Kecamatan } \\
\text { Pelayangan Kota Jambi }\end{array}$ & Pelayanan & $\underset{\mathrm{t}}{\text { Masyaraka }}$ \\
\hline 7. & $\begin{array}{l}\text { Rike Varadiyen, SE/ } \\
\text { NIP.1966080319860320 } \\
04\end{array}$ & $\begin{array}{llr}\text { Optimalisasi } & \text { Pelayanan Informasi } \\
\text { Program } & \text { PATEN } & \text { Melalui } \\
\text { Pemanfaatan } & \text { dan } & \text { Pengembangan }\end{array}$ & Pelayanan & $\begin{array}{c}\text { Masyaraka } \\
\mathrm{t}\end{array}$ \\
\hline
\end{tabular}




\section{Website Kecamatan yang Terkoneksi Dengan Keluarahan di Wilayah Kecamatan Jelutung}

Satu (1) proyek perubahan Camat Paal Merah bertemakan 'pemberdayaan" yang berkorelasi langsung kepada kelompok masyarakat sebagai pemanfaat program. Analisis lebih lanjut menunjukkan bahwa "pemberdayaan" masyarakat dilakukan dengan tahapan-tahapan sebagai berikut : pada jangka pendek membentuk kelompok-kelompok masyarakat peternak lele khusus di Kelurahan Paal Merah sebagai pilot proyek, membuat juknis yang berkaitan dengan pengelolaan tambak, dan sosialisasi program. Pada jangka menengah program sudah berjalan yang dikelola oleh kelompok-kelompok di Kelurahan Paal Merah, dan pada jangka panjang semua kelurahan di Kecamatan Paal Merah sudah membentuk kelompok-kelompok pengelola lahan terlantar.

Dua proyek perubahan yang berorientasi kepada "peningkatan kinerja aparatur" memiliki tujuan dan karakteristik yang berbeda jauh. Proyek perubahan Camat Kota Baru atas nama Feriadi, S.Sos bertemakan kinerja aparatur, akan tetapi analisis lebih lanjut menunjukkan karakteristiknya bertujuan peningkatan kinerja aparatur berorientasi langsung kepada peningkatan kualitas pelayanan yang diberikan aparatur tersebut kepada masyarakat. Dapat diartikan sebagai upaya untuk mengurangi "beban masyarakat". Berbeda dengan diatas, proyek perubahan atas nama Drs. Amran, ME Camat Alam Barajo juga berfokus pada peningkatan kinerja aparatur berorientasi pada peningkatan kapasitas ekonomi pemerintah daerah. Analisis lebih lanjut menunjukkan peningkatan kinerja aparatur akan berimplikasi pada peningkatan "beban masyarakat" karena akan diiringi dengan upaya intensifikasi dan ekstensifikasi sumber pendapatan daerah berupa pajak daerah/retribusi daerah.

Dari hasil wawancara dengan salah satu masyarakat dan hasil observasi dilapangan menunjukkan bahwa masyarakat merasa bahwa pelayanan aparatur kecamatan sudah jauh lebih baik dibandingkan dulu-dulunya, tetapi masyarakat juga merasa keberatan jika harus PBB dinaikkan karena menjadi beban masyarakat membayarnya.

Tabel 2. Jenis Manfaat Proyek Perubahan yang Diterima Target Group

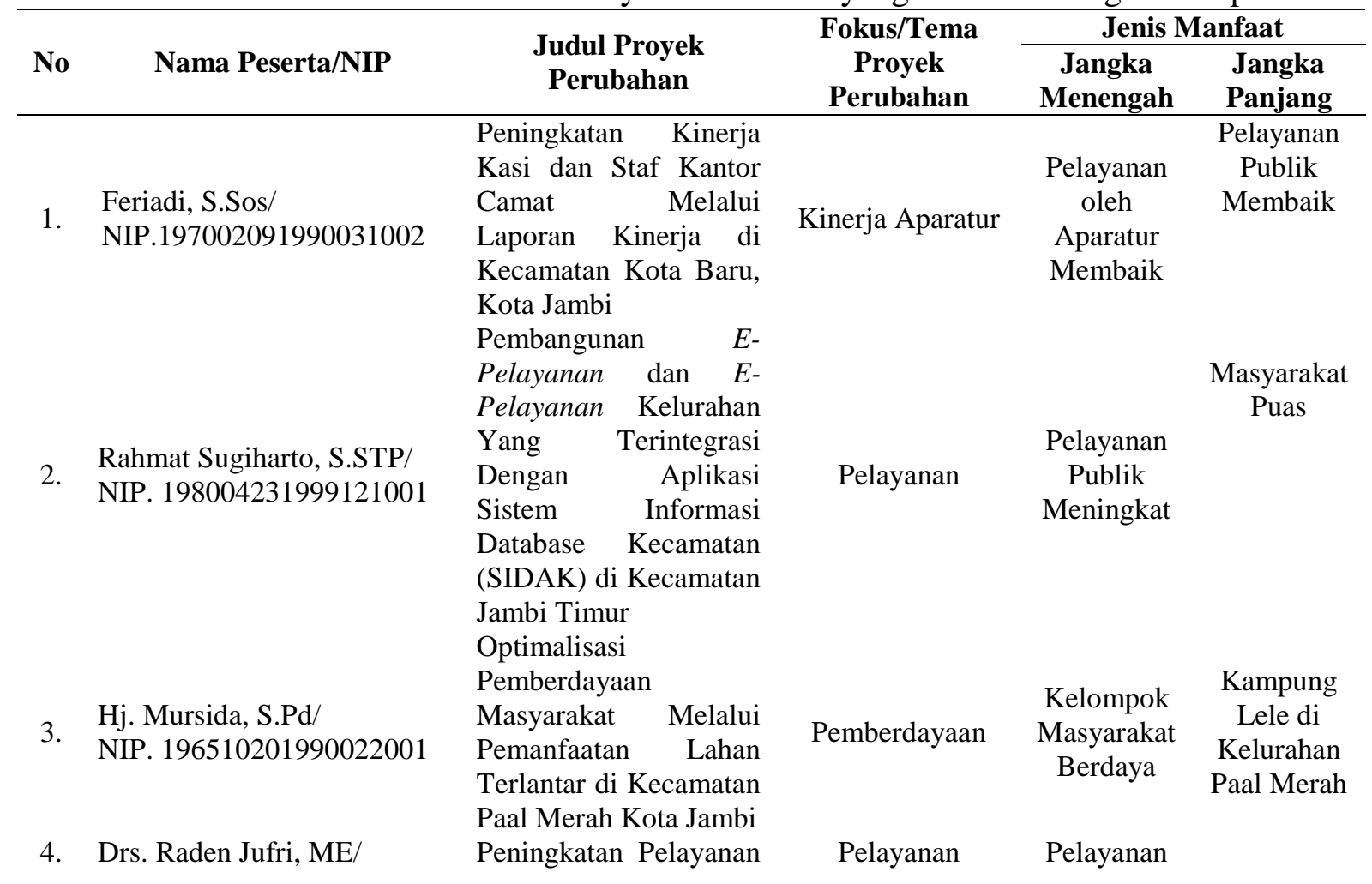




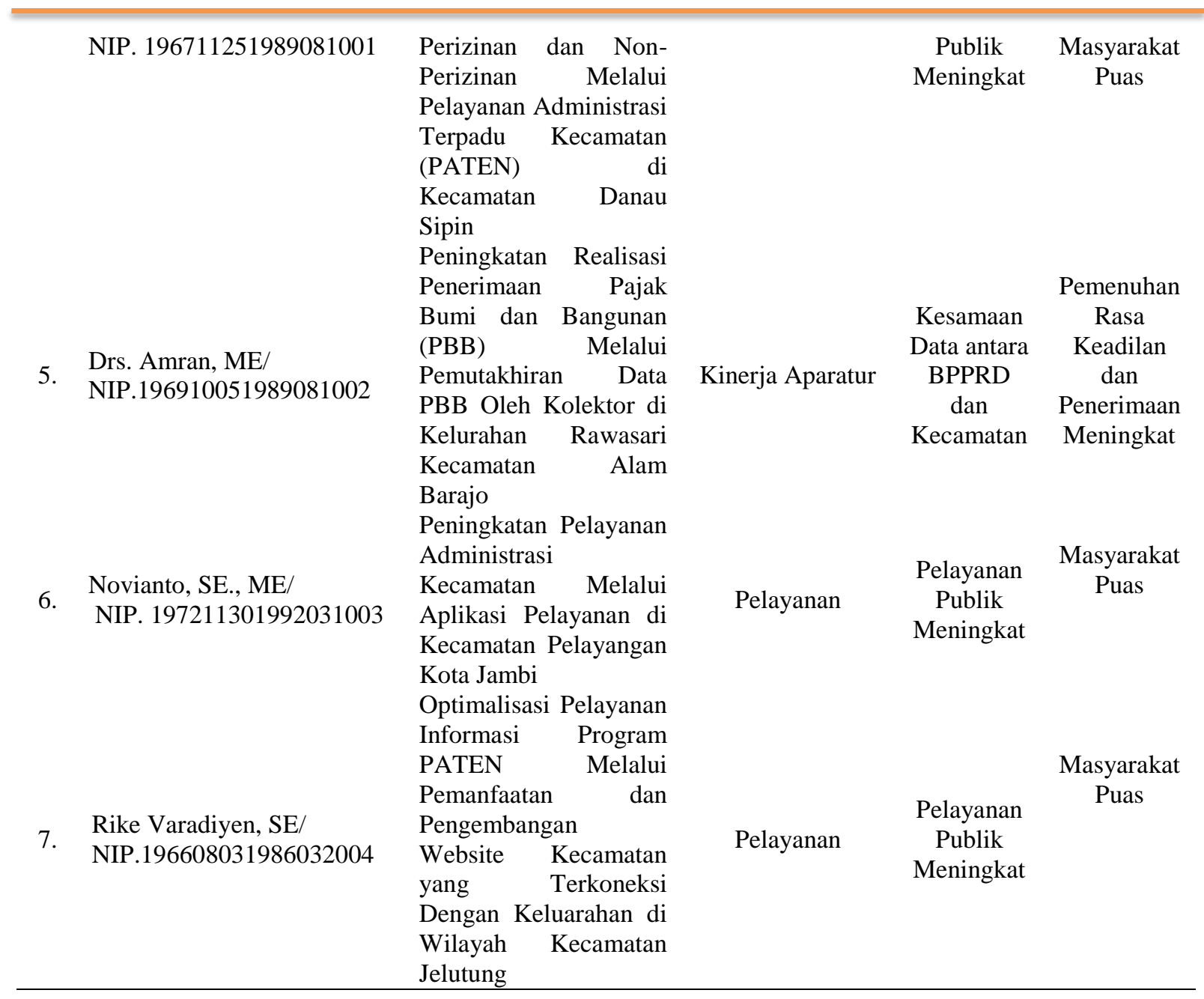

\subsection{Aspek derajat perubahan yang diharapkan.}

Derajat perubahan 4 (empat) proyek perubahan yang bertemakan "pelayanan" pada prinsipnya hampir sama yaitu meningkatkan pelayanan kepada publik melalui pemberian kemudahan pelayanan dengan meggunakan teknologi informasi dan dikenal dengan e-pelayanan. Pada jangka menengah, derajat perubahan yang dinginkan adalah tersusunnya dan terbentuknya aturan hukum, norma dan standar yang berkaitan dengan pelayanan berbasis elektronik serta sebagian sudah menyiapkan sarana dan prasarana serta peralatan yang berkaitan dengan pelayanan yang berbasis elektronik. Pada jangka panjang, derajat perubahan yang diinginkan adalah terwujudnya pelayanan publik yang berbasis elektronik atau aplikasi pelayanan. Untuk kecamatan Paal Merah yang digawangi Ibu Hj. Mursida, S.Pd pada jangka menengah derajat perubahan yang diinginkan adalah terbentuknya kelompok masyarakat yang produktif dilahan terlantar bekas Galian C. Pada jangka panjang derajat perubahannya adalah terbentuknya kampung lele di Paal Merah.

Derajat perubahan Dua (2) proyek perubahan yang bertemakan "kinerja aparatur" sebagaimana ditampilkan pada tabel 3 adalah sebagai berikut : proyek perubahan Camat Kota Baru atas nama Feriadi, S.Sos pada jangka pendek memiliki target perubahan peningkatan signifikan kedisiplinan pegawai dan dibarengi dengan peningkatan kinerja secara signifikan khusus pada pegawai dilingkungan Kantor Camat Kota Baru. Pada jangka menengah target perubahannya adalah peningkatan signifikan kedisiplinan pegawai dan dibarengi dengan peningkatan kinerja secara signifikan semua pegawai di Kecamatan Kota Baru. Dan pada 
jangka panjang target perubahannya adalah semua pegawai se Kecamatan berkinerja baik dan berkorelasi pada peningkatan pelayanan kepada masyarakat secara langsung.

Derajat perubahan yang ingin dicapai proyek perubahan Camat Alam barajo, Bapak Drs. Amran, ME adalah keinginan beliau untuk memberikan rasa keadilan bagi masyarakat banyak dalam membayar PBB. Asumsi beliau, banyak rumah hasil rehab yang secara penampakkan fisik sangat mewah, masih juga membayar PBB setahun dibawah Rp 50.000, hal ini tidak masuk akal dan tidak memberi rasa keadilan bagi rumah tangga yang biasa saja, Dan juga dilatar belakangi pesatnya perkembangan Kota Jambi dimana yang semula rumah-rumah penduduk, saat ini sudah beralih fungsi menjadi Mall, Ruko, Showroom mobil, hotel, dan lainlain.

Terkait keberatan masyarakat biasa yang bayar PBBnya naik, Amran mengatakan bahwa sesungguhna jika rumahnya tidak berubah secara total luasannya tidak akan naik secara signifikan, dan kalaupun ada kenaikan tidak akan membebani masyarakat secara nyata, paling naiknya sekitar Rp 5.000 rupiah per tahun.

Tabel 3. Derajat Perubahan Proyek Perubahan yang Diharapkan

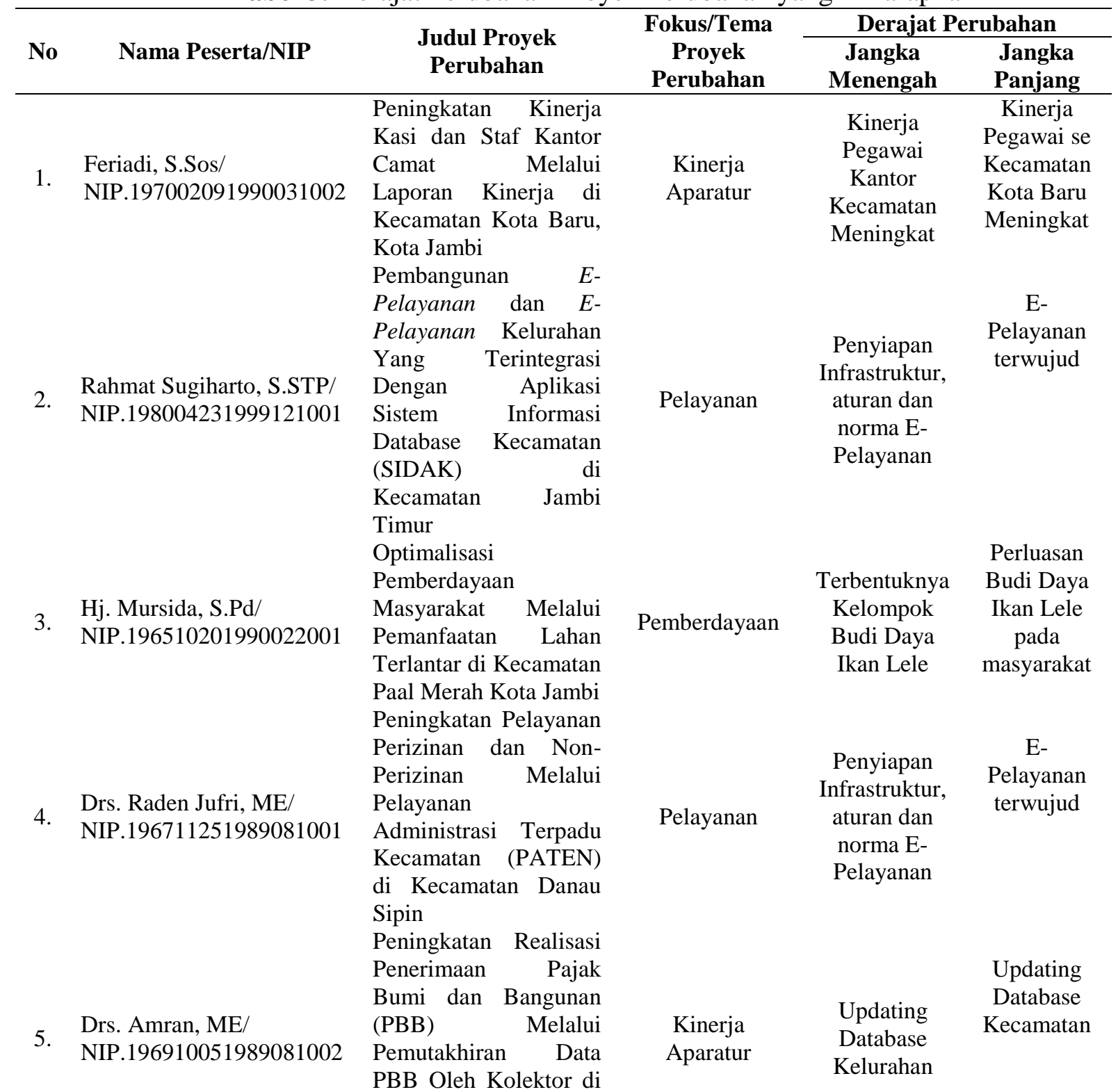




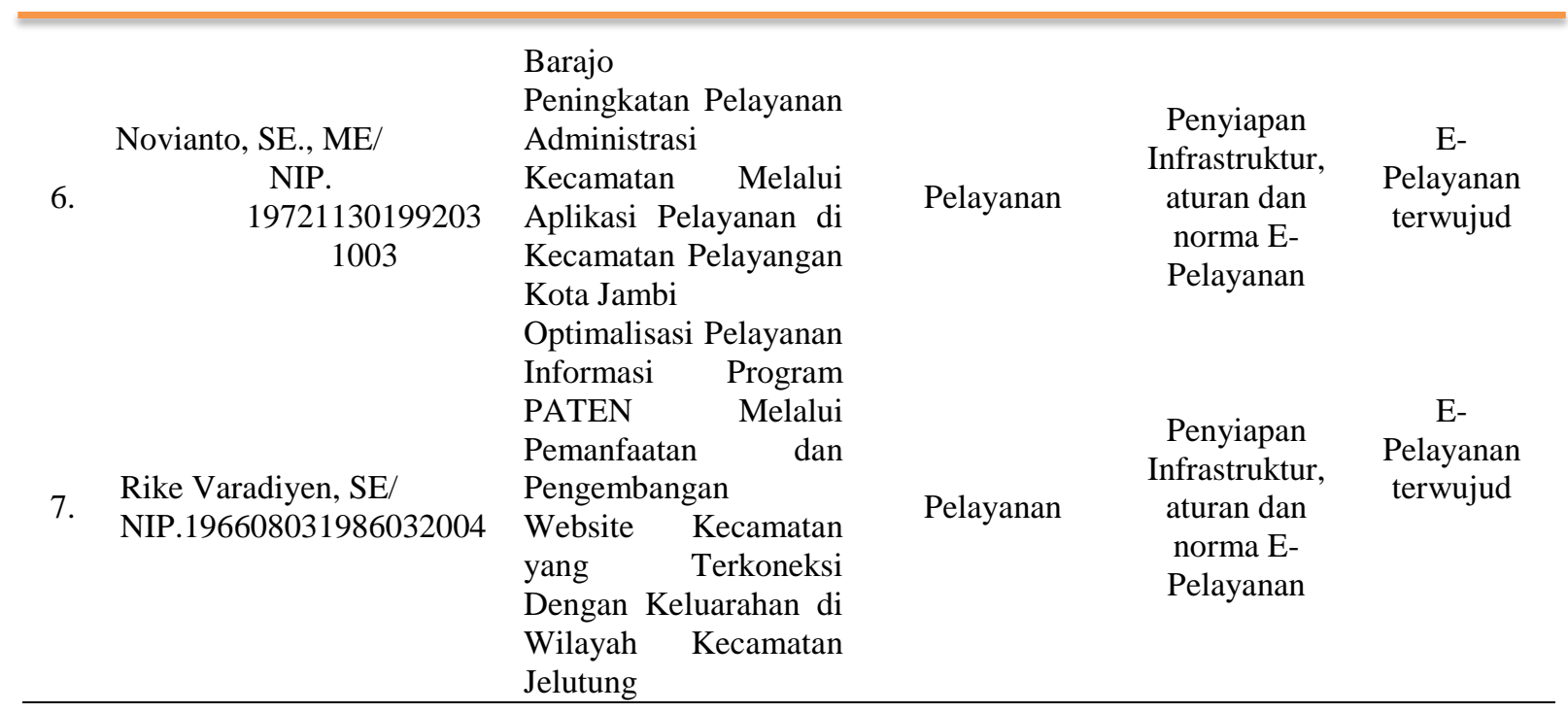

\subsection{Aspek pengambilan keputusan.}

Pada prinsipnya Camat hanya menjalankan visi dan misi kepala daerah Walikota Jambi, yaitu : "Menjadikan Kota Jambi sebagai Pusat Perdagangan dan Jasa Berbasiskan Masyarakat Berakhlak dan Berbudaya Dengan Mengedepankan Pelayanan Prima". Dengan Misinya : 1) Penguatan birokrasi dan meningkatkan pelayanan masyarakat berbasiskan teknologi informasi. 2) penguatan penegakkan hukum, trantibmas dan kenyamanan masyarakat, 3) penguatan pengelolaan infrastruktur dan utilitas perkotaan serta penataan lingkungan, 4) penguatan kapasitas ekonomi perkotaan, dan 5) meningkatkan kualitas masyarakat perkotaan. Karena proyek perubahan yang ada merupakan implementasi kebijakan Walikota Jambi, maka pengambilan keputusan pada proyek perubahan ini, semuanya dibawah kendali para camat. Lengkapnya dapat dilihat pada tabel 4 dibawah ini.

Tabel. 4 Pengambilan Keputusan pada Proyek Perubahan

\begin{tabular}{|c|c|c|c|c|c|c|}
\hline \multirow{2}{*}{ No } & \multirow{2}{*}{ Nama Peserta/NIP } & \multirow{2}{*}{$\begin{array}{l}\text { Judul Proyek } \\
\text { Perubahan }\end{array}$} & \multirow{2}{*}{$\begin{array}{c}\text { Fokus/Tema } \\
\text { Proyek } \\
\text { Perubahan }\end{array}$} & \multicolumn{3}{|c|}{$\begin{array}{c}\text { Pengambilan Keputusan } \\
\text { Oleh }\end{array}$} \\
\hline & & & & Atasan & Camat & $\begin{array}{c}\text { Pelak } \\
\text { sana }\end{array}$ \\
\hline 1. & $\begin{array}{l}\text { Feriadi, S.Sos/ } \\
\text { NIP.197002091990031002 }\end{array}$ & $\begin{array}{l}\text { Peningkatan } \\
\text { Kasi dan Staf Kantor } \\
\text { Camat Melalui Laporan } \\
\text { Kinerja di Kecamatan } \\
\text { Kota Baru, Kota Jambi }\end{array}$ & $\begin{array}{l}\text { Kinerja } \\
\text { Aparatur }\end{array}$ & & $\checkmark$ & \\
\hline 2. & $\begin{array}{l}\text { Rahmat Sugiharto, S.STP/ } \\
\text { NIP. } 198004231999121001\end{array}$ & $\begin{array}{l}\text { Pembangunan } \\
\text { Pelayanan dan E- } \\
\text { Pelayanan Kelurahan } \\
\text { Yang Terintegrasi } \\
\text { Dengan Aplikasi Sistem } \\
\text { Informasi Database } \\
\text { Kecamatan (SIDAK) di } \\
\text { Kecamatan Jambi Timur }\end{array}$ & Pelayanan & & $\checkmark$ & \\
\hline 3. & $\begin{array}{l}\text { Hj. Mursida, S.Pd/ } \\
\text { NIP. } 196510201990022001\end{array}$ & $\begin{array}{l}\text { Optimalisasi } \\
\text { Pemberdayaan } \\
\text { Masyarakat } \quad \text { Melalui } \\
\text { Pemanfaatan } \quad \text { Lahan } \\
\text { Terlantar di Kecamatan } \\
\text { Paal Merah Kota Jambi }\end{array}$ & Pemberdayaan & & $\checkmark$ & \\
\hline 4. & $\begin{array}{l}\text { Drs. Raden Jufri, ME/ } \\
\text { NIP. } 196711251989081001\end{array}$ & 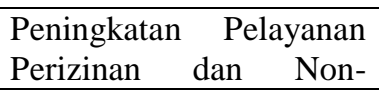 & Pelayanan & & & \\
\hline
\end{tabular}




\begin{tabular}{|c|c|c|c|c|}
\hline & & $\begin{array}{lr}\text { Perizinan } & \text { Melalui } \\
\text { Pelayanan } & \text { Administrasi } \\
\text { Terpadu } & \text { Kecamatan } \\
\text { (PATEN) di } & \text { Kecamatan } \\
\text { Danau Sipin } & \end{array}$ & & $\checkmark$ \\
\hline 5. & $\begin{array}{l}\text { Drs. Amran, ME/ } \\
\text { NIP.196910051989081002 }\end{array}$ & $\begin{array}{l}\text { Peningkatan Realisasi } \\
\text { Penerimaan Pajak Bumi } \\
\text { dan Bangunan (PBB) } \\
\text { Melalui Pemutakhiran } \\
\text { Data PBB Oleh Kolektor } \\
\text { di Kelurahan Rawasari } \\
\text { Kecamatan Alam Barajo }\end{array}$ & $\begin{array}{l}\text { Kinerja } \\
\text { Aparatur }\end{array}$ & $\checkmark$ \\
\hline 6. & $\begin{array}{l}\text { Novianto, SE., ME/ } \\
\text { NIP. } 197211301992031003\end{array}$ & $\begin{array}{lr}\text { Peningkatan } & \text { Pelayanan } \\
\text { Administrasi } & \text { Kecamatan } \\
\text { Melalui } & \text { Aplikasi } \\
\text { Pelayanan di Kecamatan } & \text { Kelayangan Kota Jambi }\end{array}$ & Pelayanan & $\checkmark$ \\
\hline 7. & $\begin{array}{l}\text { Rike Varadiyen, SE/ } \\
\text { NIP.196608031986032004 }\end{array}$ & $\begin{array}{lr}\text { Optimalisasi } & \text { Pelayanan } \\
\text { Informasi } & \text { Program } \\
\text { PATEN } & \text { Melalui } \\
\text { Pemanfaatan } & \text { dan } \\
\text { Pengembangan } & \text { Website } \\
\text { Kecamatan } & \text { yang } \\
\text { Terkoneksi } & \text { Dengan } \\
\text { Keluarahan di } & \text { Wilayah } \\
\text { Kecamatan Jelutung } \\
\end{array}$ & Pelayanan & $\checkmark$ \\
\hline
\end{tabular}

\subsection{Aspek pelaksana program sudah dirinci}

Secara umum 7 proyek perubahan yang diteliti pelaksana programnya adalah bawahan dari pengelola program. 4 proyek perubahan (Camat Jambi Timur, Jelutung, Danau Sipin dan Pelayanan) pelaksana programnya adalah dibawah koordinasi Kasi Pelayanan Umum kecamatan. 1 proyek perubahan (Camat Kota Baru) pelaksana program adalah Sekretaris Camat (Sekcam) dan Semua Kasi di kecamatan. Proyek perubahan Camat Paal Merah yang berfokus pada pemberdayaan masyarakat, pelaksananya adalah Kasi Pembangunan dan kelompok-kelompok masyarakat yang dikoordinasikan oleh perangkat RT. Dan proyek perubahan Camat Alam Barajo berfokus pada kinerja aparatur pelaksananya adalah Kasi Pemerintahan dan perangkat RT sebagai pelaksana dilapangan. Gambaran lengkapnya dapat dilihat pada tabel 5 .

Tabel 5. Pelaksana Program Proyek Perubahan

\begin{tabular}{|c|c|c|c|c|c|}
\hline \multirow[b]{2}{*}{ No } & \multirow[b]{2}{*}{ Nama Peserta/NIP } & \multirow{2}{*}{$\begin{array}{l}\text { Judul Proyek } \\
\text { Perubahan }\end{array}$} & \multirow{2}{*}{$\begin{array}{c}\text { Fokus/Tema } \\
\text { Proyek } \\
\text { Perubahan }\end{array}$} & \multicolumn{2}{|c|}{ Pelaksana Program } \\
\hline & & & & $\begin{array}{c}\text { Staf } \\
\text { Aparatur }\end{array}$ & $\begin{array}{c}\text { Bukan } \\
\text { Aparatur }\end{array}$ \\
\hline 1. & $\begin{array}{l}\text { Feriadi, S.Sos/ } \\
\text { NIP.197002091990031002 }\end{array}$ & \begin{tabular}{l}
\multicolumn{2}{l}{ Peningkatan } \\
Kinerja \\
Stas
\end{tabular} & $\begin{array}{l}\text { Kinerja } \\
\text { Aparatur }\end{array}$ & $\begin{array}{c}\text { Sekcam, } \\
\text { Kasi, Lurah, } \\
\text { Staf }\end{array}$ & Tolom \\
\hline 2. & $\begin{array}{l}\text { Rahmat Sugiharto, S.STP/ } \\
\text { NIP. 198004231999121001 }\end{array}$ & $\begin{array}{l}\text { Pembangunan E- } \\
\text { Pelayanan dan } E- \\
\text { Pelayanan } \\
\text { Kelurahan Yang } \\
\text { Terintegrasi } \\
\text { Dengan Aplikasi }\end{array}$ & Pelayanan & $\begin{array}{c}\text { Kasi } \\
\text { Pelayanan } \\
\text { Umum }\end{array}$ & - \\
\hline
\end{tabular}


3. Hj. Mursida, S.Pd/ NIP. 196510201990022001

4. Drs. Raden Jufri, ME/ NIP. 196711251989081001

5. Drs. Amran, ME/

NIP.196910051989081002

6. Novianto, SE., ME/

NIP. 197211301992031003

7. Rike Varadiyen, SE/

NIP.196608031986032004
Sistem Informasi

Database

Kecamatan

(SIDAK) di

Kecamatan Jambi

Timur

Optimalisasi

Pemberdayaan

Masyarakat

Melalui

Pemanfaatan

Lahan Terlantar

di Kecamatan

Paal Merah Kota

Jambi

Peningkatan

Pelayanan

Perizinan dan

Non-Perizinan

Melalui

Pelayanan

Administrasi

Terpadu

Kecamatan

(PATEN)

Kecamatan Danau

Sipin

Peningkatan

Realisasi

Penerimaan Pajak

Bumi dan

Bangunan (PBB)

Melalui

Pemutakhiran

Data PBB Oleh

Kolektor

Kelurahan

Rawasari

Kecamatan Alam

Barajo

Peningkatan

Pelayanan

Administrasi

Kecamatan

Melalui Aplikasi

Pelayanan di

Kecamatan

Pelayangan Kota

Jambi

Optimalisasi

Pelayanan

Informasi

Program PATEN

Melalui

Pemanfaatan dan

Pengembangan

Website

Kecamatan yang

Terkoneksi

Dengan
RT,

Kelompok

Masyarakat

Pemberdayaan $\begin{gathered}\text { Kasi } \\ \text { Pembangunan }\end{gathered}$

Kasi

Pelayanan Pelayanan

Umum

RT dan

perangkatnya

Kinerja Kasi

Aparatur Pemerintahan

Kasi

Pelayanan Pelayanan

Umum

Kasi

Pelayanan Pelayanan

Umum 


Keluarahan di
Wilayah
Kecamatan
Jelutung

\subsection{Aspek dukungan sumber daya yang memadai.}

Dalam pelaksanaan proyek perubahan masing-masing camat, dukungan sumber daya yang terlibat dibagi kedalam 2 kategori yaitu : proyek perubahan yang melibatkan masyarakat dan proyek perubahan yang tidak melibatkan masyarakat. Pada proyek perubahan yang tidak melibatkan masyarakat secara langsung misalnya yang berfokus pada pelayanan dan kinerja staf aparatur seperti pada proyek perubahan Camat-camat Jambi Timur, Jelutung, Danau Sipin, Pelayangan dan Kota Baru, maka dukungan sumber daya sudah masuk pada APBD dan sudah dianggarkan. Hanya saja pada pelaksanaannya para camat memiliki strategi sendiri bagaimana mewujudkan program kerja tersebut dengan berinovasi dan berkreasi.

Sementara itu, proyek perubahan yang melibatkan masyarakat sebagai pelaksana dilapangan, dukungan sumber daya diharapkan dari masyarakat itu sendiri dan pemerintah kecamatan hanya sebagai fasilitator saja. Pihak kecamatan juga berusaha keras untuk menyediakan sumber daya yang ada melalui kerjasama yang bersinergi dengan instansi teknis terkait. Proyek perubahan Camat Paal Merah Ibu Hj. Mursida melibatkan pihak terkait dari Dinas Pertanian, Perikanan dan Peternakan untuk membantu secara teknis dilapangan. Gambaran lengkap tentang dukungan sumber daya dapat dilihat dalam tabel 6 .

Tabel 6. Sumber Daya Proyek Perubahan dan Inovasinya

\begin{tabular}{|c|c|c|c|c|c|}
\hline No & Nama Peserta/NIP & $\begin{array}{l}\text { Tahun } \\
\text { Diklat }\end{array}$ & Judul Proyek Perubahan & $\begin{array}{c}\text { Titik } \\
\text { Inovasi }\end{array}$ & $\begin{array}{c}\text { Dukungan } \\
\text { Sumber } \\
\text { Daya }\end{array}$ \\
\hline 1. & $\begin{array}{l}\text { Feriadi, S.Sos/ } \\
\text { NIP.197002091990031002 }\end{array}$ & 2015 & $\begin{array}{l}\text { Peningkatan Kinerja Kasi dan } \\
\text { Staf Kantor Camat Melalui } \\
\text { Laporan Kinerja di Kecamatan } \\
\text { Kota Baru, Kota Jambi }\end{array}$ & E-Kinerja & $\begin{array}{l}\text { APBD Kota } \\
\text { Jambi } \\
\text { (Sekcam, } \\
\text { Kasi dan } \\
\text { Lurah, Staf) }\end{array}$ \\
\hline 2. & $\begin{array}{l}\text { Rahmat Sugiharto, S.STP/ } \\
\text { NIP.198004231999121001 }\end{array}$ & 2016 & $\begin{array}{l}\text { Pembangunan E-Pelayanan dan } \\
\text { E-Pelayanan Kelurahan Yang } \\
\text { Terintegrasi Dengan Aplikasi } \\
\text { Sistem Informasi Database } \\
\text { Kecamatan (SIDAK) di } \\
\text { Kecamatan Jambi Timur }\end{array}$ & E-Pelayanan & $\begin{array}{l}\text { APBD Kota } \\
\text { Jambi } \\
\text { (Kasi } \\
\text { Pelayanan } \\
\text { Umum) }\end{array}$ \\
\hline 3. & $\begin{array}{l}\text { Hj. Mursida, S.Pd/ } \\
\text { NIP.196510201990022001 }\end{array}$ & 2016 & $\begin{array}{lr}\text { Optimalisasi } & \text { Pemberdayaan } \\
\text { Masyarakat } & \text { Melalui } \\
\text { Pemanfaatan Lahan Terlantar di } \\
\text { Kecamatan Paal Merah Kota } \\
\text { Jambi }\end{array}$ & $\begin{array}{l}\text { Produktivitas } \\
\text { Lahan Tidur }\end{array}$ & $\begin{array}{l}\text { APBD Kota } \\
\text { Jambi dan } \\
\text { APBD } \\
\text { Provinsi } \\
\text { Jambi }\end{array}$ \\
\hline 4. & $\begin{array}{l}\text { Drs. Raden Jufri, ME/ } \\
\text { NIP.196711251989081001 }\end{array}$ & 2016 & \begin{tabular}{lr} 
Peningkatan & Pelayanan \\
Perizinan dan & Non-Perizinan \\
Melalui & Pelayanan \\
Administrasi & \multicolumn{2}{c}{ Terpadu } \\
Kecamatan & (PATEN) di \\
Kecamatan Danau Sipin
\end{tabular} & E-Pelayanan & $\begin{array}{l}\text { APBD Kota } \\
\text { Jambi } \\
\text { Kasi } \\
\text { Pelayanan } \\
\text { Umum }\end{array}$ \\
\hline 5. & $\begin{array}{l}\text { Drs. Amran, ME/ } \\
\text { NIP.196910051989081002 }\end{array}$ & 2017 & 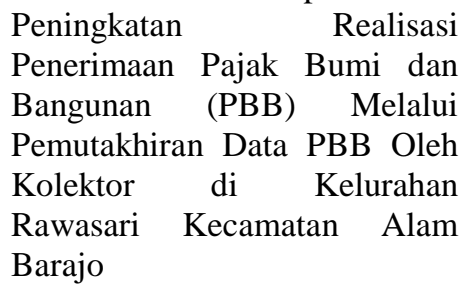 & $\begin{array}{l}\text { Updating } \\
\text { Database }\end{array}$ & $\begin{array}{l}\text { APBD Kota } \\
\text { Jambi } \\
\text { Lurah } \\
\text { Rawasari dan } \\
\text { RT }\end{array}$ \\
\hline
\end{tabular}




\begin{tabular}{|c|c|c|c|c|c|}
\hline 6. & $\begin{array}{l}\text { Novianto, SE., ME/ } \\
\text { NIP.197211301992031003 }\end{array}$ & 2017 & $\begin{array}{l}\text { Peningkatan } \\
\text { Administrasi } \\
\text { Melalui Aplikasi Pelayananan di } \\
\text { Kecamatan Pelayangan Kota } \\
\text { Jambi }\end{array}$ & E-Pelayanan & $\begin{array}{l}\text { APBD Kota } \\
\text { Jambi } \\
\text { Kasi } \\
\text { Pelayanan } \\
\text { Umum }\end{array}$ \\
\hline 7. & $\begin{array}{l}\text { Rike Varadiyen, SE/ } \\
\text { NIP.196608031986032004 }\end{array}$ & 2017 & $\begin{array}{l}\text { Optimalisasi } \\
\text { Informasi Program PATEN } \\
\text { Melalui Pemanfaatan dan } \\
\text { Pengembangan } \\
\text { Kecamatan yang Terkoneksi } \\
\text { Dengan Keluarahan di Wilayah } \\
\text { Kecamatan Jelutung }\end{array}$ & E-Pelayanan & $\begin{array}{l}\text { APBD Kota } \\
\text { Jambi } \\
\text { Kasi } \\
\text { Pelayanan } \\
\text { Umum }\end{array}$ \\
\hline
\end{tabular}

\subsection{Seberapa besar kekuasaan/kepentingan/strategi yang dimiliki oleh para aktor yang terlibat dalam implementasi kebijakan}

jika merujuk pada visi dan misi walikota, program dalam proyek perubahan yang dibuat para camat di Kota Jambi sudah sesuai dengan visi dan misi tersebut. Proyek perubahan yang dibuat oleh para camat merupakan salah satu strategi untuk mencapai visi dan misi tersebut. Analisis lebih lanjut menunjukkan bahwa Proyek Perubahan Camat Kota Baru, Camat Jambi Timur, Camat Pelayangan, Camat Jelutung, dan Camat Danau Sipin merupakan sttrategi untuk mewujudkan pencapaian Misi ke-1 Walikota Jambi, yaitu : Penguatan birokrasi dan peningkatan pelayanan masyarakat berbasiskan teknologi informasi. Camat Kota Baru proyek perubahannya cenderung berorientasi pada penguatan kapasitas birokrasi dengan berfokus pada peningkatan kinerja aparaturnya dengan tahapan di jangka pendek berfokus pada kinerja pegawai yang ada di Kantor Camat dan pada jangka menengah berfokus pada kinerja pegawai seluruh Kecamatan Kota Baru, serta pada jangka panjang penerapan e-kinerja yang pada implementasinya diambil oleh pemerintah daerah sebagai Program E-Kinerja seluruh pegawai di Kota Jambi. Kemudian untuk Camat Jambi Timur, Camat Jelutung, Camat Danau Sipin, dan Camat Pelayangan proyek perubahannya berorientasi pada peningkatan pelayanan publik dengan berfokus pada jangka menengah pembangunan data dan persiapan lainnya menuju e-pelayanan, dan jangka panjang bertujuan penerapan e-pelayanan di kecamatan sesuai dengan kemampuan dan kapasitasnya masing-masing. Keberhasilan masing-masing camat ini berbeda karena menyangkut ketersediaan dana, SDM teknis dan sarana prasarana yang ada. Kemudian, ada 2 camat yang proyek perubahannya merupakan strategi untuk mewujudkan pencapaian Misi ke-4 yaitu : "penguatan kapasitas ekonomi perkotaan". Camat Paal Merah proyek perubahannya berorientasi pada peningkatan kapasitas ekonomi kelompok masyarakat dengan melibatkan masyarakat untuk mengolah lahan terlantar (kosong) untuk digarap sebagai sumber ekonomi baru melalui budi daya ternak ikan lele. Tujuan jangka menengah proyek perubahannya adalah semua kelompok masyarakat di Kelurahan Paal Merah memiliki kolam ikan lele pada lahan terlantar yang ada di RT-RT disekitar rumah mereka. Tujuan jangka panjangnya adalah terbentuknya Kampung Lele di Kelurahan Paal Merah. Sementara untuk Camat Alam Barajo, proyek perubahannya berorientasi pada penguatan kapasitasi ekonomi kota dengan strategi peningkatan pendapatan asli daerah (PAD) melalui optimalisasi pungutan PBB perkotaan. Proyek perubahannya diawali dengan tujuan jangka menengahnya adalah penyusunan database baru pembayar PBB dan tujuan jangka panjangnya data baru tersebut sudah disahkan sebagai data daerah.

Tabel 7. Kewenangan, Kepentingan dan Strategi Aktor dalam Proyek Perubahan

\begin{tabular}{|c|c|c|c|c|c|c|}
\hline \multirow{3}{*}{$\begin{array}{c}\text { No } \\
1 .\end{array}$} & \multirow{3}{*}{$\begin{array}{l}\text { Nama Peserta/NIP } \\
\text { Feriadi, S.Sos/ }\end{array}$} & \multirow{3}{*}{$\begin{array}{l}\text { Judul Proyek } \\
\text { Perubahan } \\
\text { Peningkatan }\end{array}$} & \multirow{3}{*}{$\begin{array}{c}\text { Fokus/Tem } \\
\text { a Proyek } \\
\text { Perubahan } \\
\text { Kinerja }\end{array}$} & \multicolumn{3}{|c|}{ Peran Aktor /Camat } \\
\hline & & & & $\underset{n}{\text { Kewenanga }}$ & $\begin{array}{c}\text { Kepenting } \\
\text { an }\end{array}$ & Strategi \\
\hline & & & & & & \\
\hline
\end{tabular}




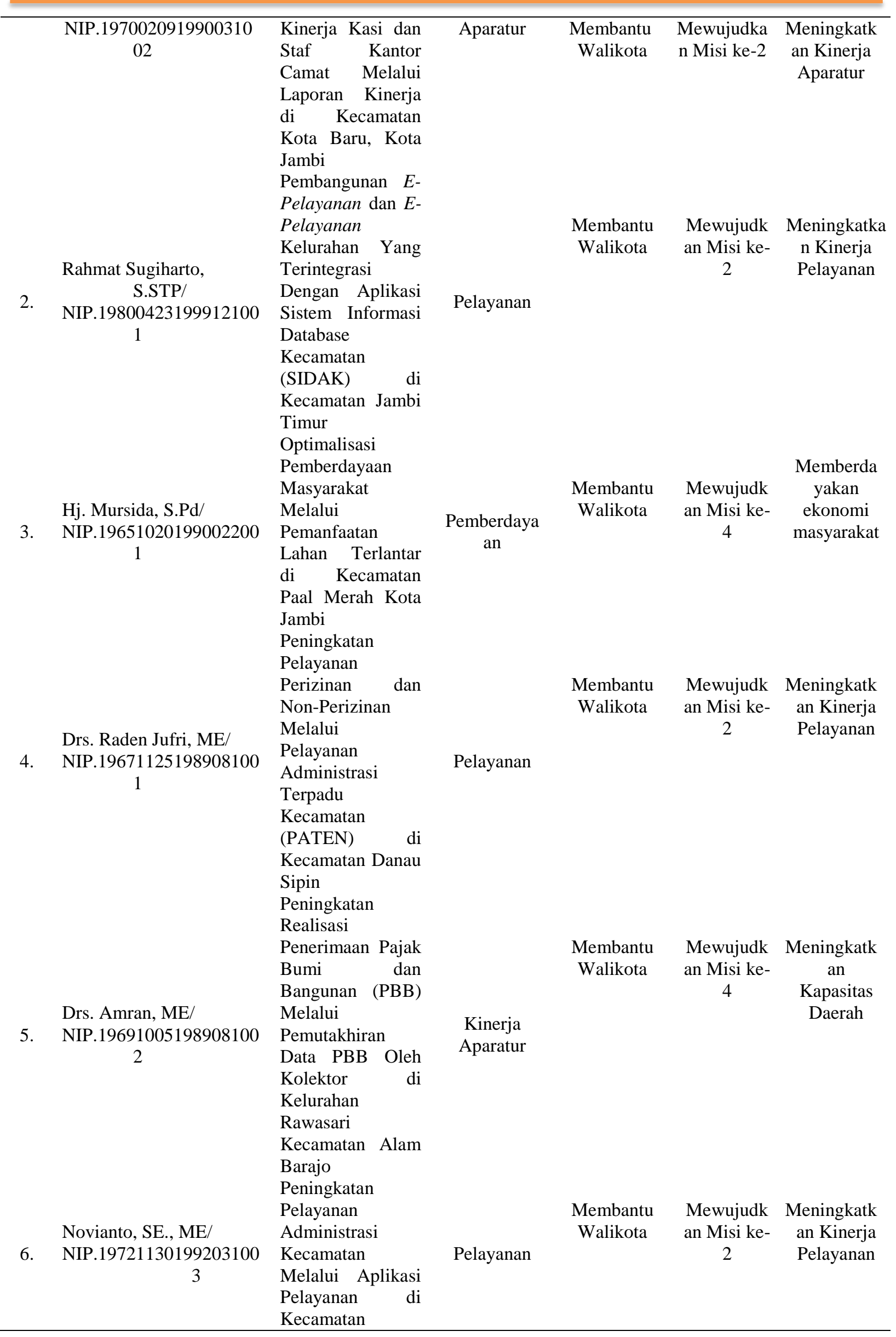




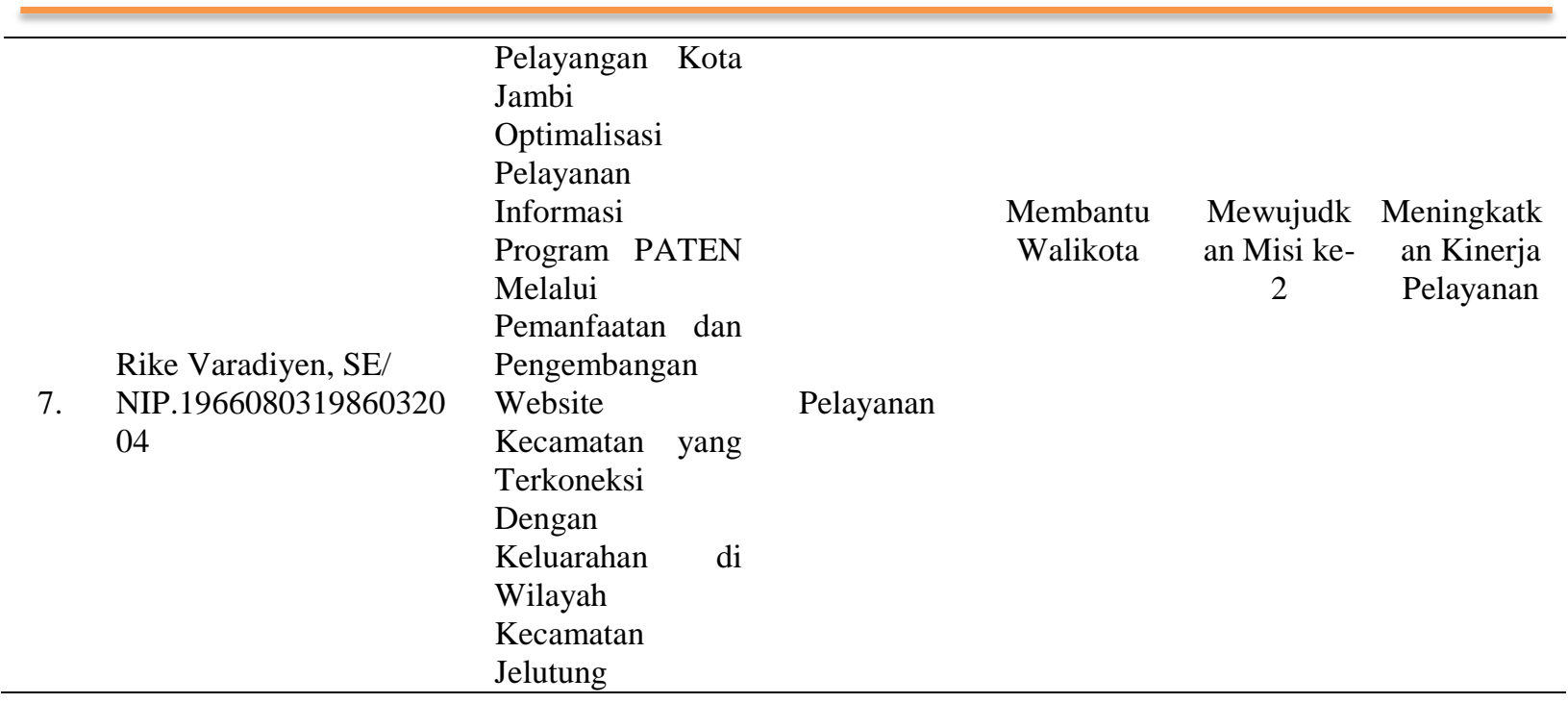

\subsection{Karakteristik rejim yang berkuasa}

Secara prinsip ciri/karakteristik rezim Walikota Jambi yang saat sedang berkuasa terdeskripsikan pada visi dan misi Kota Jambi 2018-2023. Para camat dalam Kota Jambi secara inklusif merupakan bagian daripada rezim yang saat ini sedang berkuasa. Secara otomatis semua kebijakan, program dan kegiatan yang dilakukan para camat harus merupakan tindak lanjut dari pada visi dan misi Kota Jambi. Analisis deskriptif menunjukkan bahwa rezim saat ini berorientasi pada peningkatan kepuasan masyarakat pada pelayanan publik dan penguatan kapasitas ekonomi perkotaan masyarakat kota. Jika mengacu analisis deskriptif ini, proyek perubahan para camat di Kota Jambi sudah sesuai dan merupakan refleksi dari karakteristik rezim yang berkuasa saat ini. Proyek perubahan 5 camat (Kota Baru, Jambi Timur, Danau Sipin, Jelutung dan Pelayangan) secara normatif merupakan upaya untuk meningkatkan kepuasan masyarakat terhadap pelayanan pemerintah kota, dan 2 proyek perubahan (Paal Merah dan Alam Barajo) berfokus ada peningkatan kapasitas ekonomi masyarakat kota. Proyek perubahan Camat Alam Barajo berfokus pada peningkatan kapasitas keuangan Pemerintah Kota Jambi dan proyek perubahan Camat Paal Merah berfokus pada penguatan kapasitas ekonomi kelompok-kelompok masyarakat secara langsung.

\subsection{Tingkat kepatuhan/responsivitas kelompok sasaran.}

Respon dan kepatuhan kelompok sasaran dari 7 proyek perubahan camat di Kota Jambi sangat baik. 5 proyek perubahan yang berorientasi pada pelayanan publik direspon sangat baik oleh masyarakat dan masyarakat menyatakan pelayanan publik semakin baik dan mudah. 2 Proyek perubahan yang berfokus pada penguatan kapasitas ekonomi kota memiliki tingkat respon yang berbeda, walaupun secara implisit masyarakat meresponnya secara positif. Proyek perubahan camat Paal Merah yang berfokus pada pemberdayaan ekonomi masyarakat sangat direspon positif dan didukung penuh oleh kelompok-kelompok masyarakat yang dikoordinir oleh RTRT di wilayah Paal Merah. Sementara, proyek perubahan Camat Alam Barajo respon masyarakat cenderung berhati-hati karena menyangkut iuran PBB yang harus mereka bayarkan. Gambaran lengkapnya dapat disimak pada tabel berikut :

Tabel 8. Tingkat Kepatuhan dan Responsivitas Kelompok Sasaran

\begin{tabular}{|c|c|c|c|c|}
\hline \multirow[b]{2}{*}{ No } & \multirow[b]{2}{*}{ Judul Proyek Perubahan } & \multirow[b]{2}{*}{$\begin{array}{c}\text { Fokus/Tema Proyek } \\
\text { Perubahan }\end{array}$} & \multicolumn{2}{|c|}{ Kelompok Sasaran } \\
\hline & & & Kepatuhan & $\begin{array}{c}\text { Tingkat } \\
\text { Responsiv }\end{array}$ \\
\hline
\end{tabular}




\begin{tabular}{|c|c|c|c|c|}
\hline & $\begin{array}{l}\text { Melalui Laporan Kinerja di Kecamatan Kota Baru, } \\
\text { Kota Jambi }\end{array}$ & & & \\
\hline & Pembangunan E-Pelayanan dan E-Pelayanan & & & \\
\hline 2. & $\begin{array}{l}\text { Kelurahan Yang Terintegrasi Dengan Aplikasi Sistem } \\
\text { Informasi Database Kecamatan (SIDAK) di } \\
\text { Kecamatan Jambi Timur }\end{array}$ & Pelayanan & Baik & $\begin{array}{l}\text { Sangat } \\
\text { Respon }\end{array}$ \\
\hline & Optimalisasi Pemberdayaan Masyarakat Melalui & & & Sangat \\
\hline 3. & $\begin{array}{l}\text { Pemanfaatan Lahan Terlantar di Kecamatan Paal } \\
\text { Merah Kota Jambi }\end{array}$ & Pemberdayaan & Baik & Respon \\
\hline 4. & $\begin{array}{l}\text { Peningkatan Pelayanan Perizinan dan Non-Perizinan } \\
\text { Melalui Pelayanan Administrasi Terpadu Kecamatan } \\
\text { (PATEN) di Kecamatan Danau Sipin }\end{array}$ & Pelayanan & Baik & $\begin{array}{l}\text { Sangat } \\
\text { Respon }\end{array}$ \\
\hline 5. & $\begin{array}{l}\text { Peningkatan Realisasi Penerimaan Pajak Bumi dan } \\
\text { Bangunan (PBB) Melalui Pemutakhiran Data PBB } \\
\text { Oleh Kolektor di Kelurahan Rawasari Kecamatan } \\
\text { Alam Barajo }\end{array}$ & Kinerja Aparatur & Cukup & $\begin{array}{l}\text { Kurang } \\
\text { Respon }\end{array}$ \\
\hline 6. & $\begin{array}{l}\text { Peningkatan Pelayanan Administrasi Kecamatan } \\
\text { Melalui Aplikasi Pelayanan di Kecamatan Pelayangan } \\
\text { Kota Jambi }\end{array}$ & Pelayanan & Baik & $\begin{array}{l}\text { Sangat } \\
\text { Respon }\end{array}$ \\
\hline 7. & $\begin{array}{l}\text { Optimalisasi Pelayanan Informasi Program PATEN } \\
\text { Melalui Pemanfaatan dan Pengembangan Website } \\
\text { Kecamatan yang Terkoneksi Dengan Keluarahan di } \\
\text { Wilayah Kecamatan Jelutung }\end{array}$ & Pelayanan & Baik & $\begin{array}{l}\text { Cukup } \\
\text { Respon }\end{array}$ \\
\hline
\end{tabular}

\section{PENUTUP}

Implementasi tujuan jangka menengah dan tujuan jangka panjang proyek perubahan camat alumni Diklat Kepemimpinan Tingkat III di Kota Jambi dapat terimplementasikan dengan baik. Semua faktor-faktor yang mempengaruhi impelementasi proyek perubahan yang berkaitan dengan isi kebijakan (meliputi : kepentingan kelompok sasaran, jenis manfaat yang diterima kelompok sasaran, derajat perubahan sebuah kebijakan, letak pengambilan keputusan, pelaksana program yang rinci, dan dukungan sumber daya yang terlibat) dan lingkungan kebijakan (meliputi: kepentingan/strategi aktor yang terlibat, karaktersitik rezim, dan tingkat kapatuhan kelompok sasaran) semua terdeskripsikan dengan baik dan faktor-faktor itu dapat dikelola dengan baik pula dalam menunjang impelementasi tujuan-tujuan proyek perubahan yang ada. Dapat disimpulkan bahwa implementasi tujuan jangka menengah proyek perubahan sudah berjalan baik dan sesuai dengan yang ditargetkan. Disamping itu, implementasi tujuan jangka panjang proyek perubahan juga berjalan baik dan sesuai dengan tujuannya.

Perlu dilakukan penelitian lebih lanjut menurut teori implementasi kebijakan yang lainnya, agar dapat diperbandingkan dan diketahui faktor-faktor signifikan lainnya yang dapat mempengaruhi implementasi program di kecamatan.

\section{DAFTAR PUSTAKA}

\section{Buku :}

Agostiono, 2010. Implementasi Kebijakan Publik Model Van Meter dan Van Horn, Jakarta : Rajawali Press,

Agustino, L., 2012. Dasar-Dasar Kebijakan Publik, Bandung : Penerbit Alfabeta.

Arikunto S., 2006. Prosedur Penelitian Suatu Pendekatan Praktik, Jakarta : Penerbit Rineka Cipta.

Deddy Mulyadi, 2018. Studi Kebijakan Publik dan Pelayanan Publik, Bandung : Penerbit Alfabeta. 
Howlett, Michael and M. Ramesh. 1995. Studying Public Policy: Policy Cycles and Policy Subsystem, Oxford : Oxford University Press

Purwanto E. A dan Sulistyastuti, D. R, 2012. Implementasi Kebijakan Publik Konsep dan Aplikasinya di Indonesia, Yogyakarta : Penerbit Gava Medis.

Silaen, Sofar, 2018. Metodologi Penelitian Sosial untuk Penulisan Skripsi dan Tesis, Jakarta: In Media.

Suwitri, Sri, 2008. Konsep Dasar Kebijakan Publik, Semarang : Badan Penerbit Universitas Diponegoro.

Usman, 2004. Pembangunan dan Pemberdayaan Masyarakat, Yogyakarta : Pustaka Pelajar.

Wahab, Solichin Abdul, 2002. Analisis Kebijaksanaan: dari Formulasi ke Implementasi Kebijaksanaan Negara, Jakarta : Sinar Grafika.

Wibawa S, 2005. Peluang Penerapan New Public Management Untuk Kabupaten di Indonesia, Yogyakarta: Gadjah Mada University Press

Winarno, Budi, 2008. Kebijakan Publik: Teori dan Proses, Jakarta : PT. Buku Kita.

\section{Disertasi/Tesis/Skripsi/Hasil Penelitian/Proyek Perubahan :}

Amran, SE., ME., 2017. Peningkatan Realisasi Penerimaan Pajak Bumi dan Bangunan (PBB) Melalui Pemutakhiran Data PBB Oleh Kolektor di Kelurahan Rawasari Kecamatan Alam Barajo, BPSDM Provinsi Jambi.

Feriadi, S.Sos, 2015. Peningkatan Kinerja Kasi dan Staf Kantor Camat Melalui Laporan Kinerja di Kecamatan Kota Baru, Kota Jambi, BPSDM Provinsi Jambi

Mursida, S.Pd., 2016. Optimalisasi Pemberdayaan Masyarakat Melalui Pemanfaatan Lahan Terlantar di Kecamatan Paal Merah Kota Jambi, BPSDM Provinsi Jambi.

Novianto, SE., 2017, Peningkatan Pelayanan Administrasi Kecamatan Melalui Aplikasi Pelayanan di Kecamatan Pelayangan Kota Jambi, BPSDM Provinsi Jambi

Raden Jufri, Drs.ME, Peningkatan Pelayanan Perizinan dan Non-Perizinan Melalui Pelayanan Administrasi Terpadu Kecamatan (PATEN) di Kecamatan Danau Sipin, BPSDM Provinsi Jambi.

Rahmat S, 2016. Pembangunan E-Pelayanan dan E-Pelayanan Kelurahan Yang Terintegrasi Dengan Aplikasi Sistem Informasi Database Kecamatan (SIDAK) di Kecamatan Jambi Timur. BPSDM Provinsi Jambi.

Rike Varadiyen, SE., 2017. Optimalisasi Pelayanan Informasi Program PATEN Melalui Pemanfaatan dan Pengembangan Website Kecamatan yang Terkoneksi Dengan Keluarahan di Wilayah Kecamatan Jelutung, BPSDM Provinsi Jambio

Rotinsulu, F., 2018. Sinopsis Orasi Ilmiah : Implementasi Tujuan Jangka Menengah Proyek Perubahan Oleh Alumni Diklat Kepemimpinan Tingkat III Pola Baru (Studi Kasus pada Sekretariat Daerah Provinsi Sulawesi Utara), BPSDM Provinsi Sulawesi Utara

\section{Peraturan Perundang-undangan :}

Perkalan Nomor 19 Tahun 2015 tentang Pedoman Penyelenggaraan Pendidikan dan Pelatihan Kepemimpinan Tingkat III, LAN RI, Jakarta.

Perkalan Nomor 4 Tahun 2017 tentang Pedoman Pelaksanaan Orasi Ilmiah Widyaiswara, LAN RI, Jakarta 